\title{
INTERNALISASI DIMENSI INTERKULTURAL PERMAINAN GENDANG DALAM KOMUNITAS DANGDUT KOPLO: SEBUAH KAJIAN KONSTRUKSI SOSIAL
}

\author{
Denis Setiaji \\ Pengkajian Musik \\ Pascasarjana Institut Seni Indonesia Surakarta \\ setiajidenis@gmail.com
}

\begin{abstract}
ABSTRAK
Penelitian ini difokuskan untuk melihat proses terkonstruksinya dimensi interkultural pada pola permainan gendang terhadap pelaku dan para pecinta Dangdut Koplo. Pendekatan yang digunakan mengadopsi dari Ilmu Sosial yakni teori konstruksi sosial Peter L. Berger yang terdiri dari eksternalisasi, objektivasi, dan internalisasi. Penelitian yang dilakukan menggunakan metode fenomenologi dengan melakukan studi lapangan ke sejumlah wilayah pertunjukan Dangdut Koplo di Solo Raya terutama Taman Hiburan Rakyat (THR) Sriwedari dengan objek kelompok musik Areva sebagai bahan studi kasus. Proses konstruksi sosial masyarakat Dangdut Koplo dideskripsikan melalui analisis pada transkrip pola-pola gendang dan dampak musikalnya. Tahap eksternalisasi melibatkan konsep dan kreativitas Areva dalam menghasilkan serta mengembangkan dimensi interkultural pada pola permainan gendang. Kreativitas dalam bentuk pola-pola gendang bermuatan proses interkultural dihadirkan dengan melibatkan interaksi intersubjek sehingga menghasilkan produk interaktif berupa senggakan dan gerak-gerak komunitas joged pada proses objektivasi. Media pentas dan konser menjadi proses sosialisasi yang membuat masyarakat dari satu kolektif ke kolektif lain, melihat Areva Musik sebagai manifestasi dari Dangdut Koplo, pada tahap internalisasi.
\end{abstract}

Kata kunci: pola gendang, dimensi interkultural, konstruksi sosial

\begin{abstract}
This research focused on the construction process of intercultural dimension of the drums pattern among Dangdut Koplo's society. The approach used to adopt from the social sciences, that was social construction theory from Peter $l$. Berger consist of externalization, internalization, and objectivation. Research conducted using the method of Phenomenology by doing fieldwork to a number of area performing Live of Dangdut Koplo in Solo and surroundings especially on Taman Hiburan Rakyat (THR) Sriwedari with Areva Music group as a case study. The process of social construction of society Dangdut Koplo described through analysis on transcripts of drum patterns and the impact of its. Externalization stage involves the concept of creativity from Areva Music in generating and developing intercultural dimension on the drum pattern of the gendang's player. Creativity in the form of many drum patterns featured intercultural process involving the subject to subject interaction to produce interactive products in the form of senggakan and some motion from joged's community on the process of objectivation. The medium of performances and concerts into a process of socialization that make communities from one another, the collective to collective see that Areva Music group as a manifestation of Dangdut Koplo, at the process of internalization.
\end{abstract}

Keywords: drums pattern, dimension of intercultural, sosial construction

\section{A. Pendahuluan}

Dangdut koplo (atau Koplo) adalah sebuah bentuk musik dangdut daerah yang berasal dari Jawa Timur. Bentuk dangdut daerah memperlihatkan tingkat kreatifitas artistik yang memadukan bahasa daerah, elemen musik, dan atau pelaksanaan pertunjukannya. Dangdut koplo memiliki pola gendang yang khas, irama cepat, campuran genre musik lain, dan gaya berjoget yang erotis. Dangdut koplo muncul pada pertengahan tahun 1990-an bersamaan dengan perubahan situasi politik dan ekonomi, peningkatan akses pada teknologi, pengurangan produksi rekaman lokal, dan desentralisasi industri musik. Sebagai studi kasus, dangdut koplo memperlihatkan sebuah formasi genre musik baru pada era pasca reformasi Indonesia (Weintraub, 2013:160).

Kemunculannya di era tahun 90-an di Jawa Timur kemudian mulai "meledak" di media nasional melalui fenomena "ngebor" Inul Daratista. 
Akar historis Dangdut Koplo tidak terlepas dari perkembangan dangdut dari era sebelumnya, namun terdapat perbedaan yang cukup signifikan. Pusat perbedaan paling esensial terletak pada pola tabuhan/pukulan gendang-ketipung. Pola tabuhan gendang dangdut sebelumnya mengadopsi permainan tabla (pola chalte) di India, sedangkan dangdut koplo menggunakan pola chalte yang dimainkan dengan tempo yang lebih cepat serta mengadopsi pola-pola pukulan instrumen di dalam musik tradisional, sehingga terkesan lebih atraktif dan dinamis.

Pada perkembangannya Koplo mulai menyebar kesejumlah wilayah di luar Jawa Timur. Pengaruh kelompok Koplo Jawa Timur paling dominan berpengaruh di daerah-daerah Jawa Tengah terutama wilayah utara dan juga wilayah sekitar perbatasan Jawa Timur dan Jawa Tengah. Hal tersebut dapat terindikasi terutama secara musikal dan berbagai unsur Koplo yang diadopsi oleh kelompok-kelompok di luar Jawa Timur. Pengadopsian musikal yang paling dominan ialah aransemen lagu terutama pola-pola permainan gendangnya.

Dangdut Koplo mengembangkan popularitasnya di tengah ketegangan politik dan masa yang disebut masyarakat Indonesia sebagai "zaman edan" terutama masa krisis ekonomi dan jatuhnya kepemimpinan presiden Suharto pada Mei 1998 (Aspinal, 2003:235). Transformasi ekonomi dan politik mempengaruhi kehidupan budaya populer.

Dangdut Koplo menjadi salah sebuah pergerakan ekonomi penting dalam musik populer Indonesia dan mendapatkan popularitasnya tidak hanya di Jawa Timur sebagai basis utama, akan tetapi telah menyebar di sejumlah daerah lainnya. Koplo merupakan bentuk dari pan-regional musik yang membedakan dangdut koplo, karena telah melebur dengan musik-musik daerah seperti campur sari (Jawa Tengah), kendang kempul (Banyuwangi), dan pop Sunda (Jawa Barat), tarling (Cirebon) dan daerah lainnya (Weintraub, 2013:183).

Koplo juga merupakan bentuk kreativitas yang terbentuk melalui proses interkultural sejumlah kelompok etnik. Mendominasi pasar nasional walaupun banyak terpengaruh bentuk-bentuk lokalitas (Weintraub, 2013:168). Bentuk-bentuk interkultural tersebut menurut penulis juga tercermin pada unsur musikal dari koplo. Terutama dari pola-pola pukulan gendangnya. Pada akhirnya sangat dimungkinkan pada tataran permainan gendang, terdapat sejumlah dimensi interkultural di dalamnya. Hal tersebut penulis asumsikan sebagai sesuatu yang paling esensial dalam Dangdut Koplo. Akhirnya penulis mencoba mendeskripsikan bentuk-bentuk dimensi interkultural yang ada pada fenomena musikal terutama pada permainan gendangnya.

Hingga kini dangdut koplo terus eksis diikuti dengan perkembangan kreativitas dan repertoar lagu yang semakin bertambah di daerah masingmasing. Secara perlahan dimulai dari pergerakan musikal dan pertunjukannya, dangdut koplo membentuk masyarakat atau komunitasnya. Masyarakat tersebut yang terdiri dari para praktisi dan penikmatnya memiliki konsep tertentu mengenai koplo itu sendiri. Dangdut koplo lambat laun melalui sebuah proses sehingga melekat dengan kehidupan para kelompok "produser" dan "apresiator", termasuk penubuhan dimensi interkultural pada koplo. Akhirnya menjadi pertanyaan ialah seperti apakah proses dangdut koplo hingga membentuk sebuah realitas sosial. Penulis menggunakan studi kasus sejumlah kelompok dangdut koplo dan komunitas Koplo di wilayah Solo Raya seperti O.M Savana dan Areva Music pimpinan Arief dari Karangmojo Tasikmadu, Karanganyar sebagai bahan analisis. Pemilihan Areva sebagai bahan analisis utama disebabkan popularitas dan kreativitas kelompok tersebut dewasa ini sedang digandrungi berbagai kalangan pecinta Dangdut Koplo terutama di wilayah Solo Raya. Kemudian komunitas joged Temon Holic, serta tempat konser dangdut koplo di wilayah tersebut terutama Taman Hiburan Rakyat (THR) Sriwedari Solo.

Guna mendeskripsikan konsep Koplo serta menganalisis proses internalisasi dari dimensi interkultural dalam Dangdut Koplo, penulis menggunakan teori konstruksi sosial Peter L. Berger. Konstruksi sosial tersebut terdiri dari eksternalisasi sebagai penyesuaian diri dengan dunia sosio-kultural sebagai produk dunia manusia, objektivasi berupa proses interaksi sosial dalam dunia intersubjektif yang dilembagakan atau mengalami proses institusionalisasi, dan internalisasi yang merupakan proses individu mengidentifikasikan diri dengan lembaga-lembaga tempat individu menjadi anggotanya (Sukidin, 2002:202). Pada kasus di atas yakni bagaimana para praktisi Dangdut Koplo menciptakan konsep pola permainan gendang sehingga terdapat dimensi interkultural di dalamnya (eksternalisasi), kemudian konsep diimplementasikan dengan pola-pola permainan gendang tersebut 
berinteraksi baik antara pemain dengan pemain maupun pemain dengan para penonton (objektivasi), dan bagaimana pada akhirnya pola-pola gendang tersebut kemudian terserap oleh para praktisi maupun penonton menjadi sebuah bentuk realitas yang mereka maknai sebagai Dangdut Koplo (internalisasi). Untuk menganalisis persoalan musikal menggunakan notasi dengan simbol-simbol yang dibuat penulis dengan mengadopsi model transkrip notasi angka di dalam musikologi.

\section{B. Kehadiran Dangdut Koplo}

Kemunculannya di era tahun 90-an di Jawa Timur kemudian mulai "meledak" di media nasional melalui fenomena "ngebor" Inul Daratista. Akar historis Dangdut Koplo tidak terlepas dari perkembangan dangdut dari era sebelumnya, namun terdapat perbedaan yang cukup signifikan. Pusat perbedaan paling esensial terletak pada pola tabuhan/pukulan gendang-ketipung. Pola tabuhan gendang dangdut sebelumnya mengadopsi permainan tabla (pola chalte) di India, sedangkan dangdut koplo menggunakan pola chalte yang dimainkan dengan tempo yang lebih cepat serta mengadopsi pola-pola pukulan instrumen di dalam musik tradisional, sehingga terkesan lebih atraktif dan dinamis.

Pada perkembangannya Koplo mulai menyebar kesejumlah wilayah di luar Jawa Timur. Pengaruh kelompok Koplo Jawa Timur paling dominan berpengaruh di daerah-daerah Jawa Tengah terutama wilayah utara dan juga wilayah sekitar perbatasan Jawa Timur dan Jawa Tengah. Hal tersebut dapat terindikasi terutama secara musikal dan berbagai unsur Koplo yang diadopsi oleh kelompok-kelompok di luar Jawa Timur. Pengadopsian musikal yang paling dominan ialah aransemen lagu terutama pola-pola permainan gendangnya.

Dangdut Koplo mengembangkan popularitasnya di tengah ketegangan politik dan masa yang disebut masyarakat Indonesia sebagai "zaman edan" terutama masa krisis ekonomi dan jatuhnya kepemimpinan presiden Suharto pada Mei 1998 (Aspinal, 2003:235). Transformasi ekonomi dan politik mempengaruhi kehidupan budaya populer.

Dangdut Koplo menjadi salah sebuah pergerakan ekonomi penting dalam musik populer Indonesia dan mendapatkan popularitasnya tidak hanya di Jawa Timur sebagai basis utama, akan tetapi telah menyebar di sejumlah daerah lainnya. Koplo merupakan bentuk dari pan-regional musik yang membedakan dangdut koplo, karena telah melebur dengan musik-musik daerah seperti campur sari (Jawa Tengah), kendang kempul (Banyuwangi), dan pop Sunda (Jawa Barat), tarling (Cirebon) dan daerah lainnya (Weintraub, 2013:183). Spirit kedaerahan memang menjadi ciri khas dari Dangdut Koplo salah satunya yakni lirik-lirik dengan bahasa daerah (misal bahasa Jawa dan Banyuwangi), termasuk kolaborasi ritmik seni-seni daerah yang ada dalam kategori tradisional.

\section{Pola permainan Gendang}

Komposisi instrumen pada pertunjukan Dangdut Koplo notabene sama dengan musik Dangdut pada umumnya namun, yang membedakan ialah perlakuan pemain melalui kreativitasnya terhadap instrumen, salah satunya gendang /ketipung. Dangdut Koplo secara musikal dipengaruhi oleh berbagai jenis genre musik seperti pada kutipan di bawah ini,

"However, koplo was not a separate genre from dangdut but rather a musical treatment or style of dangdut (that blended other genres of music including rock, pop, and local Javanese songs)... dangdut koplo is characterized by its distinctive drum pattern, fast tempo, genre-bending arrangements, and eroticized spectacle of performance (Weintraub, 2013: 161)".

(Bagaimanapun, koplo bukanlah genre yang terpisah dari dangdut (telah menyatu dengan genregenre lain seperti rock, pop, dan lagu-lagu lokal Jawa)... dangdut koplo terkarakterisasi melalui pola tabuhan khusus, tempo cepat, "pembengkokan" aransemen-aransemen genre, dan pertunjukan yang cenderung terlihat erotis).

Kutipan di atas menjelaskan mengenai unsurunsur utama yang melekat pada Koplo seperti instrumen utama (gendang ketipung), irama yang cenderung bertempo cepat, mendaur sebuah genre ke dalam bentuk Dangdut Koplo, dan pertunjukan biduan yang cenderung menampilkan erotisme sehingga menjadi daya tarik tersendiri bagi pecinta Dangdut Koplo.

Tabuhan atau pola-pola gendang ketipung menjadi semacam aktor utama di dalam pertunjukan Koplo. Hal tersebut dikarenakan konsep kekoploan dalam dangdut terletak pada permainan gendang yang cepat, variatif, dan membuat suasana menjadi semarak. Seperti literatur yang penulis kutip di bawah ini, 
"Pada faktor musik, Dangdut Koplo sangat kental dengan pengaruh berbagai gaya musikal, termasuk rock, house, Dangdut dan Jaipongan. Pada iringan musiknya, Dangdut Koplo dominasi gendang Dangdut yang bersuarakan "dang". Permainan "dang" lebih dominan dibanding "dut", bunyi ini dihasilkan melalui teknik menggeser tangan di lapisan kulit/membrane gendang. Dampak yang terjadi ketika "dang" lebih dominan membuat suasana semakin semarak (Raditya, 2013: 7)".

Selain persoalan suasana yang terbentuk oleh variasi pukulan gendang ketipung, terdapat pula informasi tentang adanya persentuhan antara musik dangdut sebagai musik populer dengan Jaipongan yang menjadi salah satu kesenian tradisional di Jawa Barat.

Citra Koplo menurut pemahaman penulis, terbentuk melalui pola permainan Gendangnya. Secara umum gendang Dangdut terdiri dari dua buah penghasil suara, yakni kecil dan besar. Gendang besar menghasilkan suara "dang", "dut", dan "duut", sedangkan gendang kecil menghasilkan suara "tak" dan "tung".

Suara "dang" dan "dut" dihasilkan dengan memukul bagian tengah gendang besar dengan menggunakan jari tengah atau telunjuk, perbedaannya apabila "dang" suaranya lebih rendah (low) sedangkan "dut" cenderung lebih tinggi (high), yang diakibatkan penempatan ujung telapak tangan di atas kulit gendang besar. Suara "duut" dengan teknik seperti membunyikan suara "dang" dan "dut" namun, disertai dengan mendorong (slide) ujung telapak tangan dari pinggir luar kulit gendang ke tengah kulit gendang. Gendang kecil menghasilkan suara "tak" dengan memukul pinggiran kulit dengan jari telunjuk (umum), dibunyikan dengan jari ditekan dan ditempelkan pada ujung kulit gendang kecil, sedangkan suara "tung" dibunyikan agak ke tengah kulit dengan tidak mengunakan tekanan seperti membunyikan "tak", saat membunyikan jari yang memukul tidak ditempelkan pada kulit gendang kecil, artinya ketika membunyikan jari yang memukul langsung diangkat dari permukaan kulit gendang kecil.

Menurut sebuah sumber, perbedaan pola dasar permainan gendang Dangdut dan Dangdut Koplo, seperti di bawah ini,

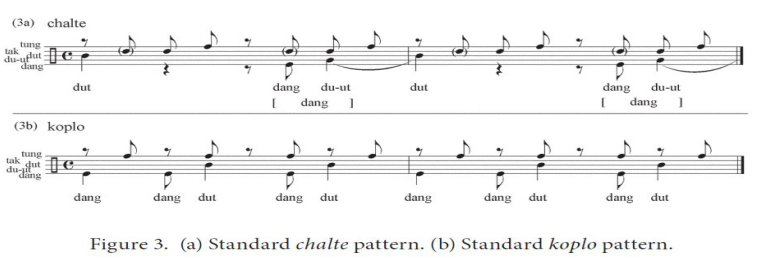

(Weintraub, 2013: 168)

Ada sedikit perbedaan penemuan yang ditulis oleh Weintraub dengan fakta musikal yang penulis temukan di lapangan. Salah satu narasumber mas Ndandut seorang pengendang O.M Savana dari Karang Anyar menyebutkan bahwa dalam Dangdut Koplo sumber bunyi yang diolah pengendang lebih variatif. Pada gendang kecil dihasilkan bunyi "tek", "tak", "tuk", "tung", dan "trrt", sedangkan pada gendang besar terdapat suara "dang", "dut", "det", dan "ndedet". Dari karakter bunyi berbedabeda tersebut diolah sedemikian rupa menghasilkan sejumlah pola-pola pukulan Dangdut Koplo yang sangat beragam. Instrumen gendang pada perkembangannya dilengkapi dengan instrumen perkusif yang diadopsi dari berbagai kesenian tradisional seperti, kendhang ciblon, kendhang reog, kendhang banyuwangen, kendang jaipong, dan lain sebagainya. Hal tersebut dilakukan oleh para pemain gendang untuk menghasilkan variasi suara, terutama karakter suara dengan rasa etnik yang kental. Selain menggunakan instrumen tradisional adapula yang menggunakan teknologi synthetizer yang menggunakan suara atau audio sampling dari sejumlah instrumen etnik, sehingga memudahkan para pengendang dalam mencapai karakter suara instrumen tradisional tertentu yang diinginkan.

\section{E. Dimensi Interkultural Pada \\ Permainan Gendang Dangdut Koplo}

Interkultural berarti antar-budaya, terkadang disebut pula sebagai komunikasi antar budaya yang memiliki kebudayaan yang berbeda (KBBI). Apabila melihat fakta musikal pada unsur pembentuk Dangdut Koplo, terutama pola-pola permainan gendangnya, mencerminkan adanya proses adaptasi pukulan gendang dari sejumlah seni tradisi di berbagai wilayah budaya. Hal di atas menghasilkan sebuah "ruang musikal" yang penulis sebut sebagai dimensi interkultural.

Pada kasus penelusuran pola bentuk gendangan Koplo, ditemukan beberapa pendapat yang berbeda. Malik B.Z seorang komposer dari lagu "Keagungan Tuhan" mengklaim bahwa pola-pola Koplo berasal pola tabuhan lokal yakni seni Reog Ponorogo dari Jawa Timur. Pengendang dari Jawa Barat berasumsi bahwa permainan utama gendang 
Koplo mengimitasi iringan pada gendang pada tarian Sunda yakni Jaipongan, atau dikenal dengan pola mincid. Hal tersebut rupanya dibenarkan oleh para pengendang dari Jawa Timur khususnya di Surabaya dan Banyuwangi (Weintraub, 2013: 198). Salah satu orkes bernama Monata mengklaim bahwa kelompoknya beraliran "Jarandut Koplo" (Jaranan dan Dangdut Koplo) dimana aransemen lagu yang dibuat memasukan unsur kesenian Jaranan (kuda kepang, kuda lumping, dsb) tidak terkecuali pada tabuhan gendang ketipungnya. Orkes dangdut lainnya yang notabene terkenal dengan pola gendangannya seperti kelompok Sera, Sagita, dan lainnya, terkadang menggunakan sejumlah idiom lokal yang dipadukan di dalam satu repertoar lagu. Sebuah lagu misalnya, menggunakan permainan ketipung yang mengadopsi pola-pola jaipongan, reogan, banyumasan, hingga jaranan. Kehadiran pola tabuhan tersebut memberikan kesan tertentu yang membuat citra Koplo berbeda dari pertunjukan Dangdut sebelumnya serta menambah suasana "Koplo" yang ada dalam setiap pertunjukan. Hal tersebut menjadikan gendang sebagai menjadi paling esensial dalam Dangdut Koplo.

Hal di atas juga terdapat pada kelompok Koplo di daerah Solo raya (Solo dan eks-karesidenan Surakarta) salah satunya kelompok musik Areva juga sangat terpengaruh dengan gaya permainan gendang dari orkes dangdut besar di wilayah Jawa Timur seperti O.M New Pallapa. Beberapa pola permainan gendang yang mencitrakan dimensi interkultural tersebut di antaranya,

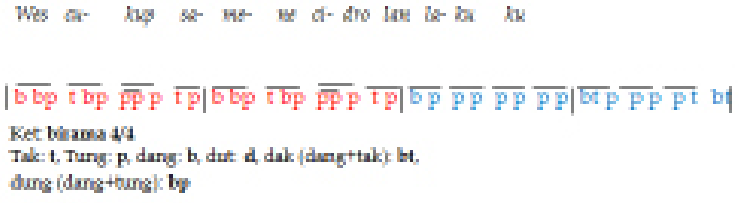

Pola Gendang 1

Pola mincid (jaipong) (merah) dan jaranan atau reogan (biru) pada potongan lagu Tembang Tresno oleh O.M New Pallapa dalam acara pernikahan di

Tanjung Kedamean, Gresik 21 September 2016 (Sumber: Maxtones Production)

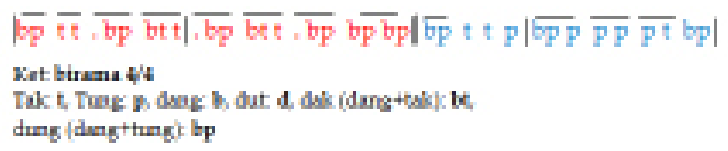

Pola Gendang 2

Pola chalte (India) (merah) dan jaranan atau reogan (biru) pada intro lagu Tembang Tresno oleh O.M New Pallapa dalam acara pernikahan di Tanjung Kedamean, Gresik 21 September 2016

(Sumber: Maxtones Production)

Berangkat dari fenomena di atas, dalam polapola pukulan gendang Koplo terdapat muatan idiom-idiom musik lokal dari sejumlah komunitas kebudayaan yang diimitasi sebagai bahan baku aransemen sebuah lagu. Fenomena di atas memperlihatkan sebuah dimensi interkultural seperti pada kutipan di berikut "These creative appropriations illustrate intercultural processes among ethnic groups, rather than the dominance of national forms over local ones (Weintraub, 2013: 168)". Pola-pola permainan yang mencitrakan dimensi interkultural di atas menyebar kesejumlah wilayah dan di adopsi oleh kelompok-kelompok di luar wilayah Jawa Timur untuk dikembangkan kembali seperti pada kasus kelompok Areva Music yang menjadikan wilayah Solo Raya sebagai basis eksistensinya.

\section{F. Eksternalisasi Dimensi Interkultural Permainan Gendang DK}

Konstruksi Sosial masyarakat Dangdut Koplo di awali dengan proses yang dinamakan eksternalisasi. Berger (1991:4) menyatakan bahwa eksternalisasi ialah sebuah kondisi penyesuaian diri dengan dunia sosio-kultural sebagai produk manusia. Suatu implementasi ke dalam dunia, baik berupa aktivitas fisik maupun mental. Pada kasus Dangdut Koplo, terutama dalam hal ini ialah bagaimana para pengendang memiliki konsep yang diproses melalui kreativitas untuk menciptakan pola-pola permainan gendang yang memiliki muatan-muatan interkultural di dalamnya. Kreativitas tersebut tercipta melalui proses pengalaman yang pada kasus ini ialah pengendang. Para pengendang maupun praktisi Dangdut Koplo lain tentunya merealisasikan konsep yang dimiliki melalui aktivitas fisik yakni menciptakan pola-pola gendang dengan komposisi ragam unsur seni di berbagai wilayah budaya. Aktivitas fisik tersebut tentunya merupakan produk auditif yang dihasilkan oleh praktisi Dangdut Koplo.

Areva merupakan salah satu kelompok musik dengan basis genre Dangdut Koplo yang eksistensinya sedang ramai diperbincangkan di 
kalangan masyarakat penikmat Koplo terutama di wilayah Solo dan Sekitarnya. Areva ialah salah satu kelompok yang memiliki ciri-ciri sajian Koplo yang dipengaruhi oleh orkes dari Jawa Timur seperti O.M New Pallapa dan O.M Sera. Areva sebagai kelompok musik Dangdut Koplo membuat konsepkonsep tertentu dari segi aransemen lagu termasuk pola-pola permainan gendangnya yang membuat mereka populer di kalangan penikmat Koplo.

Dalam momen eksternalisasi kenyataan sosial ditarik keluar dari individu. Pada momen ini, realitas sosial berupa adaptasi dengan norma, nilai, dan sebagainya yang hal itu semua berada diluar diri manusia, sehingga dalam proses konstruksi sosial melibatkan momen adaptasi diri atau di adaptasikan antara peraturan tersebut dengan dunia sosio-kultural (Sanderson, 2003:21). Kelompok Areva pada kasus ini mencoba melakukan adaptasiadaptasi berkaitan dengan kreativitas mereka dalam meracik sajian Koplo yang dibingkai dalam konsep Areva Musik Horee. Praktisi Areva dalam hal ini pengendang mencoba memproyeksikan ide-idenya melalui pengembangan dimensi interkultural yang kombinasikan dengan variasi-variasi tertentu. Termasuk di dalamnya bagaimana ragam pola gendang dengan basis proses interkultur yang dibuat mampu pula membentuk senggakan yang juga variatif.

\section{G. Objektivasi Dimensi Interkultural \\ Permainan Gendang Dangdut Koplo}

Pada tahap selanjutnya, "ruang" interkultural tersebut diimplementasikan dalam produk auditif berupa pola-pola gendang yang pada kasus ini adalah proses objektivasi oleh kelompok musik Areva. Objektivasi yakni proses penuangan sejumlah aktivitas kreasi sehingga berinteraksi dengan antar personal baik antar praktisi maupun para penikmat Dangdut Koplo. Menurut Berger (1991:4-5) objektivasi adalah disandangnya produk-produk aktivitas itu dalam interaksi sosial dengan intersubjektif yang dilembagakan atau melalui proses institusional. Proses institusional tersebut adalah sebuah usaha agar sebuah nilai atau produk aktivitas dapat dikenal, dihargai, dan ditaati. Pada kasus ini, kelompok Areva melakukan penuangan karakteristik Koplo yang mereka konstruksi berbasis dimensi interkultural yang mereka kembangkan. Sehingga pada akhirnya dapat didengar dan dinikmati oleh antar individu dalam masyarakat Dangdut Koplo. Di bawah ini merupakan contoh dari pola-pola yang terindikasi memiliki muatan dimensi interkultural yang dilakukan oleh kelompok Areva Music,

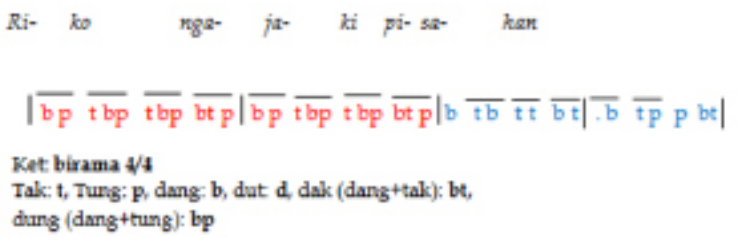

Pola Gendang 3

Pola mincid (jaipong) (merah) dan

banyumasan(biru) pada potongan lagu Lungset oleh Areva Music dalam acara milad Temon Holic di Taman Jurug Solo 8 Mei 2016 (Sumber: Studio 7 Multimedia)

Transkrip di atas memperlihatkan dimensi interkultural yang terjadi di dalam pola permainan gendang oleh kelompok Areva. Hal di atas hampir mirip dengan transkrip permainan kelompok di Jawa Timur seperti New Pallapa pada pembahasan sebelumnya. Fenomena tersebut menjadi indikasi pengaruh kelompok dari Jawa Timur sebagai basis utama penyebaran Dangdut Koplo. Kelompok Areva mencoba menjadikan basis Koplo di atas sebagai landasan kreativitas untuk diintegrasikan dengan konsep yang mereka miliki. Salah satu contoh benang merah dimensi interkultural pada pola gendang 3 di atas dikolaborasikan kembali dengan pola lainnya,

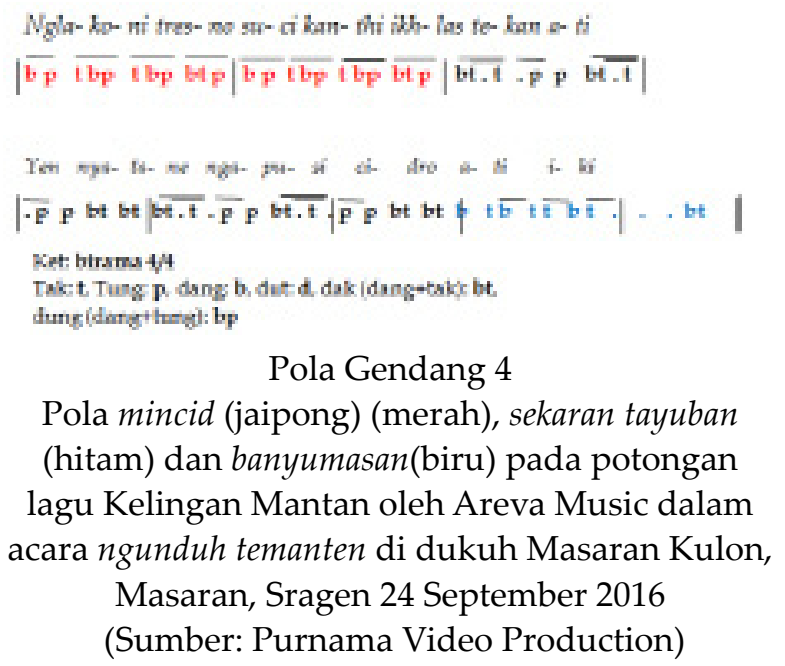

Pola Gendang 4

Pola mincid (jaipong) (merah), sekaran tayuban (hitam) dan banyumasan(biru) pada potongan lagu Kelingan Mantan oleh Areva Music dalam acara ngunduh temanten di dukuh Masaran Kulon, Masaran, Sragen 24 September 2016 (Sumber: Purnama Video Production)

Pola gendang di atas memperlihatkan pengembangan yang dilakukan oleh kelompok Areva untuk membuat pola gendang yang lebih variatif dengan menggabungkan pola sekaran kendhang yang mirip 
dan sering dipakai dalam pertunjukan Tayub ataupun terkadang terdapat pada sekaran kendhangan pada langgam Jawa.

Pada proses objektivasi di atas mensyaratkan adanya interaksi yang terjadi dari konsep kreativitas dalam diri praktisi yang dalam hal ini ialah pemain gendang yang berperan sebagai produsen dimensi interkultural. Penulis membagi interaksi dalam proses objektivasi tersebut yakni antara pemain dengan pemain, pemain dengan penonton, dan penonton dengan penonton. Interaksi antar subjek di atas yang terjadi dalam proses objektivasi dimensi interkultural yang dimunculkan dalam bentuk polapola gendang oleh praktisi Koplo tersebut.

Interaksi antara pemain dengan pemain yakni bagaimana pemain gendang (produsen primer) berhubungan dengan pemain lainnya seperti pemain keyboard, tamborin, dan gitar (produsen sekunder) dalam melakukan pertunjukan Dangdut Koplo, khususnya sajian pada setiap repertoar lagu. Pemain gendang memiliki kedudukan khusus dalam Dangdut Koplo, hal tersebut dapat terlihat dalam setiap sajian, para pemain (tamborin, keyboard, gitar dalam konteks Areva Music) selalu mengikuti pola-pola permainan gendang, terutama pada aksen-aksen dalam variasi yang dilakukan.

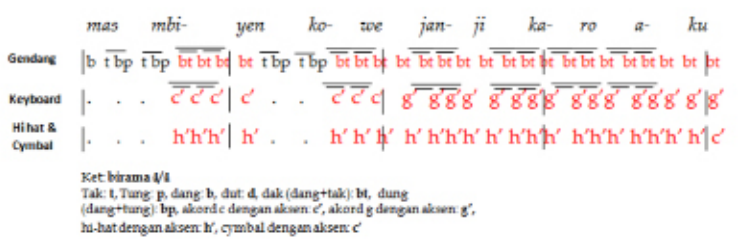

Pola Gendang 5

Pola variasi gendang (aksen) diikuti oleh aksen instrumen keyboard, hi-hat, dan cymbal pada potongan lagu Kelingan Mantan oleh Areva Music dalam acara ngunduh temanten di dukuh Masaran

Kulon, Masaran, Sragen 24 September 2016

(Sumber: Purnama Video Production)

Selain mengikuti aksen-aksen pada pola-pola gendang, kecenderungan selanjutnya yakni munculnya senggakan-senggakan terutama cenderung dilakukan oleh pemain tamborin. Senggakan memang sering ditemukan dalam konteks karawitan, yang diartikan sebagai vokal bersama atau tunggal yang menggunakan kata-kata (terkadang tanpa makna) yang berfungsi untuk mendukung terwujudnya nuansa ramai dalam sajian suatu gendhing atau lagu (Poerwadarminta,1939:557). Pada konteks Dangdut Koplo, senggakan juga menunjuk pada persoalan yang sama. Kata-kata yang sering dilakukan oleh kelompok Areva Music (pemain tomborin khususnya) seperti "Hak 'e!", "Hok'ya!", “Sololololow!", “oa!", “oe!", “ao!", “ea!" “aha!", "asooy" dan sebagainya. Hal di atas sejalan dengan sumber di bawah ini,

Pembeda Dangdut dan Dangdut Koplo pada permainan Kendang yang membentuk ruang senggakan. Senggakan dalam mengisi repertoar demi repertoar lagu. Senggakan terbukti membedakan tempo musik, patahan-patahan musik serta memberikan efek yang lebih enerjik dan lebih partisipasif dalam keberlangsungannya (Raditya, 2013: 184).

Senggakan pada Dangdut Koplo terbentuk oleh stimulasi permainan gendang. Pola-pola gendang membentuk ruang-ruang kemungkinan munculnya senggakan. Kata-kata yang menjadi senggakan dapat menempel pada pukulan gendang atau pola ketukannya, hingga mengisi ketukan-ketukan kosong dimana gendang tidak dibunyikan.

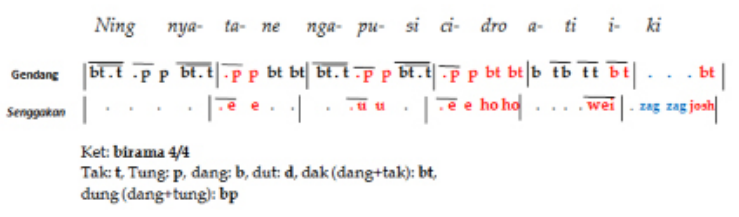

Pola Gendang 6

Pola variasi gendang dengan senggakan mengikuti ketukan (merah) dan mengisi ketukan kosong (biru) pada potongan lagu Kelingan Mantan oleh Areva Music dalam acara ngunduh temanten di dukuh Masaran Kulon, Masaran, Sragen 24 September 2016

(Sumber: Purnama Video Production)

Fakta di atas memperlihatkan bagaimana pola gendang memberikan ruang untuk para pemain (biasanya pemain tamborin) untuk melakukan sejumlah senggakan untuk membuat atmosfer pertunjukan semakin ramai. Kemudian interaksi pemain dan pemain menjadi proses penting kaitannya dengan objektivasi. Selain pemain dengan pemain, ruang senqqakan iuga terialin antara pemain dan penonton.

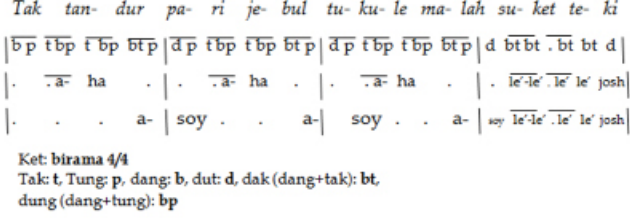

Pola Gendang 7

Pola gendang dengan senggakan pemain dan 
penonton pada potongan lagu Kelingan Mantan oleh Areva Music dalam acara ngunduh temanten di dukuh Masaran Kulon, Masaran, Sragen 24

September 2016

(Sumber: Purnama Video Production)

Hal di atas menjadi salah satu interaksi yang sering dilakukan antara pemain dan penonton, terutama dalam setiap pertunjukan yang digelar oleh Areva. Salah satu keunikan dan hal yang membuat pecinta Dangdut Koplo nantikan dalam setiap pertunjukan Areva musik, ialah interaksi pemain dengan penonton yang menyebabkan chemistry musikal yang terjadi di antaranya.

Selain interaksi melalui sarana senggakan, sejumlah pola-pola gendang variatif terutama oleh kelompok Areva Musik, menstimulan kreativitas para penonton untuk menciptakan gerakan joged yang tertata, unik, lucu, dan kreatif. Sehingga munculah sejumlah komunitas joged yang terkenal salah satunya ialah Temon Holic. Pola-pola permainan gendang hasil pengembangan dimensi interkultural tersebut ditangkap oleh komunitas joged sebagai bahan baku kreativitas mereka dalam setiap pertunjukan Dangdut Koplo. Komunitas Temon Holic menjadi fenomena tersendiri dalam perkembangan masyarakat Dangdut Koplo. Polapola permainan gendang yang variatif semacam "candu" yang membawa mereka kealam kepuasan batin tertentu. Anggota komunitas tersebut harus memiliki kepekaan terhadap kemungkinan pola permainan gendang seperti apa yang akan didengar dan bagaimanakah implementasi gerak yang akan mereka ciptakan terhadap pola tersebut.

Menurut Syam (2005:44), pelembagaan akan terjadi manakala terdapat kesepahaman intersubjektif atau antar subjek-subjek. Pada kasus di atas khususnya pada eksistensi kelompok Areva Musik, dari mulai permainan gendang diikuti aksen-aksen musikal oleh pemain instrumen lainnya, hadirnya ruang senggakan antara pemain dengan pemain maupun pemain dengan penonton, dan munculnya komunitas joged yang menjadikan pola-pola gendangan Koplo sebagai bahan baku kreativitasnya, telah mencerminkan bagaimana dimensi interkultural pada Dangdut Koplo melembaga melalui sejumlah interaksi di dalamnya.

\section{Internalisasi Dimensi Interkultural Permainan Gendang DK}

Pada proses selanjutnya kreativitas kelompok
Areva Musik ialah pada tahap akhir dari proses konstruksi sosial, yakni internalisasi dari objek kreatif khususnya dimensi interkultural pada permainan gendang dalam setiap pentas. Menurut Bungin (2007:48-49) internalisasi adalah peresapan kembali realitas-realitas yang ada di luar individu dan mentransformasikannya dari struktur dunia objektif ke dalam struktur dunia subjektif. Melalui internalisasi, dunia realitas sosial yang objektif tersebut dimasukan kembali ke dalam diri individu, sehingga seakan-akan berada dalam diri individu. Artinya bagaimana pola-pola gendang dengan muatan dimensi interkultural yang dilakukan kelompok Areva kemudian masuk mengendap pada setiap subjek dalam wilayah Dangdut Koplo. Sehingga setiap individu melihat bahwa Areva Musik melalui kreativitasnya ialah manifestasi dari Dangdut Koplo.

Tentunya Areva Musik melalui proses panjang terutama pada konteks ini yang berkaitan dengan sosialisasi. Panggung ke panggung dari mulai event kecil maupun event konser dengan ribuan penonton menjadi wadah sosialisasi kreativitas yang mereka lakukan seperti di THR Sriwedari maupun diseputaran wilayah Solo Raya dan sekitarnya. Setiap perfom adalah sosialisasi yang menjadi kepanjangan tangan dari proses objektivasi. Hal tersebut untuk menjaga citra Areva dengan muatan dimensi interkultural di dalamnya untuk tetap lestari. Seperti pada kutipan di bawah ini,

Oleh karena itu, untuk melestarikan identifikasi tersebut maka digunakanlah sosialisasi. Dalam hidup bermasyarakat, manusia senantiasa dituntut untuk mampu menyesuaikan diri dengan lingkungan sosialnya melalui suatu proses. Proses ini dapat disebut proses penyesuaian diri individu ke dalam kehidupan sosial, atau lebih singkat dapat disebut dengan sosialisasi (Abdulsyani, 2012: 57).

Melalui sosialisasi yang dilakukan dalam kurun waktu tertentu, pengendapan terjadi dalam setiap individu terutama komunitas Dangdut Koplo. Salah satu contoh bagaimana komunitas Joged secara spontan dapat mengidentifikasi pola-pola permainan yang dibawakan oleh pemain gendang Areva Musik sebagai untuk diproduksi ulang menjadi sejumlah gerak-gerak joged yang menarik. Hal tersebut juga berlaku dalam identifikasi senggakan yang dilakukan pemain maupun penonton sebagai hasil dari proses pengendapan melalui pola-pola gendang. 
Menurut Sukidin (2002:218) pengendapan intersubjektif dinamakan sosial bila sudah diobjektivasi dalam sistem tanda. Berlakunya sistem tanda memungkinkan pengalaman-pengalaman tersebut dialihkan dari satu generasi ke generasi atau dari suatu kolektivitas ke kolektivitas lain. Sistem tanda dalam kasus Areva Musik tentunya berkaitan dengan karakteristiknya saat memproduksi pola-pola gendang. Sehingga, para penikmat Koplo dapat mengidentifikasi bahwa model-model permainan gendang tersebut merepresentasikan konsep Koplo dari Areva Musik, hasil pengembangan dari pola-pola yang mengandung unsur dimensi interkultural. Kesemuanya melebur di dalam diri setiap penikmat Koplo khususnya di Solo Raya oleh berbagai kalangan, dan dari komunitas ke komunitas. Sehingga Areva Musik pada akhirnya mengkonstruksi konsep musik yang mereka usung di tengah-tengah masyarakat Dangdut Koplo.

\section{J. Simpulan}

Gendang dalam Dangdut Koplo memiliki posisi strategis hingga menciptakan dimensi interkultural di dalamnya. Sejumlah kelompok dalam hal ini Areva Musik menjadi salah satu agen yang mengkonstruksi masyarakat Dangdut Koplo di wilayah Solo raya dan sekitarnya. Konsep dan kreativitas mereka menjadi bagian dari proses eksternalisasi, termasuk penuangan dimensi interkultural dalam pola-pola gendang yang dimainkan. Pola-pola gendang yang mengandung proses interkultural tersebut dihadirkan menjadi produk auditif yang melibatkan interaksi intersubjek, antara pemain dengan pemain, maupun pemain dengan penonton, dalam proses objektivasi. Proses objektivasi melalui sejumlah sosialisasi berbentuk pentas-pentas maupun konser Dangdut Koplo yang dilakukan Areva Musik, menghasilkan pengendapan di antara penikmat termasuk para praktisi, sehingga terbentuklah makna Dangdut Koplo yang dapat diidentifikasi oleh masyarakatnya pada tahap internalisasi.

\section{Daftar Pustaka}

Abdulsyani. Sosiologi Skematik: Teori dan Terapan. Jakarta: Bumi Aksara, 2012.

Berger, Peter L. Langit Suci: Agama Sebagai Realitas Sosial. Jakarta: LP3ES, 1991.

Bungin, Burhan. Sosiologi Komunikasi: Teori, Paradigma, dan Diskursus Teknologi di Masyarakat.
Jakarta: Kencana, 2007.

Fealy, Aspinall, Edward, and Greg. Local Power and Politics in Indonesia: Decentralisation \& Democratisation. Singapore: ISEAS, 2003.

Purwadarminta. Badesastra Djawa. Batavia. J.B Walter Utgevers Maatschappijnv Gronigen, 1939

Raditya, Michael Haryo Bagus. Tesis. “Esensi Senggakan Pada Dangdut Koplo Sebagai Identitas Musikal". Fakultas Ilmu Budaya Universitas Gadjah Mada (UGM) Yogyakarta, 2013.

Sukidin, Basrowi. Metode Penelitian Kualitatif Pespektif Mikro. Surabaya: Insan Cendekia, 2002.

Syam, Nur. Islam Pesisir. Yogyakarta: LKIS, 2005.

Weintraub, Andrew N. The Sound and Spectacle of Dangdut Koplo: Genre and Counter-Genre in East Java, Indonesia. Asian Music Summer/fall, 2013. 